\title{
Trans-9, Cis-11 Conjugated Linoleic Acid Reduces Milk Fat Synthesis in Lactating Dairy Cows ${ }^{1}$
}

\author{
J. W. Perfield II, ${ }^{2}$ A. L. Lock, ${ }^{\star 3}$ J. M. Griinari,† A. Sæbø,‡ P. Delmonte,§ D. A. Dwyer, ${ }^{\star}$ and D. E. Bauman ${ }^{\star 4}$ \\ *Department of Animal Science, Cornell University, Ithaca, NY 14853 \\ †University of Helsinki, Department of Animal Science, Helsinki, Finland \\ $\ddagger$ Natural ASA, Hovdebygda, Norway \\ $\S$ Center for Food Safety and Applied Nutrition, US Food and Drug Administration, College Park, MD 20740
}

\begin{abstract}
Under certain dietary situations, rumen biohydrogenation results in the production of unique fatty acids that inhibit milk fat synthesis. The first of these to be identified was trans-10, cis-12 conjugated linoleic acid (CLA), but others are postulated to contribute to dietinduced milk fat depression (MFD). Our objective was to examine the potential role of trans-9, cis-11 CLA in the regulation of milk fat. In a preliminary study, we used gas-liquid and high-performance liquid chromatography techniques to examine milk fat samples from a diet-induced MFD study and found that an increase in trans-9, cis-11 CLA corresponded to the decrease in milk fat yield. We investigated this further using a CLA enrichment of 9, 11 isomers to examine the biological effect of trans-9, cis-11 CLA on milk fat synthesis. Four rumen-fistulated Holstein cows were randomly assigned in a $4 \times 4$ Latin square experiment involving 5$\mathrm{d}$ treatment periods and abomasal infusion of 1 ) ethanol (control), 2) a 9, 11 CLA mix (containing $32 \%$ trans -9 , cis-11, 29\% cis-9, trans- 11 , and $17 \%$ trans -9 , trans- 11 ), 3) a trans-9, trans-11 CLA supplement, and 4) a trans10, cis-12 CLA supplement (positive control). The trans9, trans-11 CLA and trans-10, cis-12 CLA supplements were of high purity $(>90 \%)$, and all supplements were infused at a rate to provide $5 \mathrm{~g} / \mathrm{d}$ of the CLA isomer of interest. Milk yield and dry matter intake did not differ among treatments. Compared with the control treatment, milk fat yield was reduced by $15 \%$ for the 9,11
\end{abstract}

Received November 8, 2006.

Accepted January 4, 2007.

${ }^{1}$ Supported in part by the National Research Initiative Competitive Grants Program, Cooperative State Research, Education, and Extension Service, United States Department of Agriculture (grant 200635206-16643), and the Cornell Agricultural Experiment Station.

${ }^{2}$ Current address: Jean Mayer United States Department of Agriculture Human Nutrition Research Center on Aging at Tufts University, Boston, MA 02111.

${ }^{3}$ Current address: Department of Animal Science, University of Vermont, Burlington, VT 05405.

${ }^{4}$ Corresponding author: deb6@cornell.edu
CLA mixture and by $27 \%$ for the trans-10, cis-12 CLA treatment. We also found that trans-9, trans-11 CLA had no effect on milk fat yield, and previous research has shown that milk fat yield is unaltered when cows are infused with cis-9, trans-11 CLA. When all treatments were considered, results suggested that trans9, cis-11 was the CLA isomer in the 9, 11 CLA mix responsible for the reduction in milk fat synthesis, although the magnitude was less than that observed for trans-10, cis-12 CLA. Interestingly, trans-9, trans-11 CLA altered the milk fat desaturase index, further demonstrating that alterations in desaturase can occur independently of effects on milk fat synthesis. Overall, our investigations identified that an increase in milk fat content of trans-9, cis-11 CLA was associated with diet-induced MFD and provided evidence of a role for this isomer in MFD based on the $15 \%$ reduction in milk fat yield with abomasal infusion of a CLA enrichment that supplied $5 \mathrm{~g} / \mathrm{d}$ of trans-9, cis-11 CLA.

Key words: conjugated linoleic acid, milk fat depression, lactation, cow

\section{INTRODUCTION}

Milk fat is markedly affected by nutrition, and a striking example of this is the phenomenon of milk fat depression (MFD). Diet-induced MFD represents a challenging problem that involves the interrelationship between bacterial fermentation in the rumen and the synthesis of milk fat by the mammary glands. The biohydrogenation theory proposes that under certain dietary situations, the pathways of rumen biohydrogenation are altered, and this results in the production of unique fatty acid intermediates that act at the mammary gland as potent inhibitors of milk fat synthesis (Bauman and Griinari, 2001). Thus, changes in the rumen outflow of many fatty acids including trans-18:1 and conjugated linoleic acid (CLA) isomers occur, and as a consequence, the milk fat concentrations of these fatty acids are often correlated with MFD (Loor et al., 2005; Roy et al., 2006; Shingfield et al., 2006). However, 
correlations do not establish a causal relationship, and the identification of specific biohydrogenation intermediates that regulate milk fat synthesis requires direct testing, which is often limited by analytical techniques and availability of these specific fatty acids.

The first biohydrogenation intermediate to be identified as a potent inhibitor of milk fat synthesis was trans10, cis-12 CLA (Baumgard et al., 2000). A summary of subsequent studies using varying doses of pure trans10, cis-12 CLA demonstrated the curvilinear reduction in milk fat yield that occurs as the concentration of trans-10, cis-12 CLA increases in milk fat (de Veth et al., 2004). However, comparisons of the dose-response relationship with that observed in various situations of diet-induced MFD suggest the existence of additional fatty acids that inhibit milk fat synthesis (Bauman and Griinari, 2001; Perfield et al., 2002; Peterson et al., 2003). More recently, Sæbø et al. (2005) demonstrated that cis-10, trans-12 CLA also caused a reduction in milk fat synthesis.

Our objective was to identify and test potential regulators of milk fat synthesis associated with diet-induced MFD. Our approach was to first use a novel HPLC method to characterize the CLA isomer profile using milk fat samples from a study in which trans-10, cis12 CLA was inadequate to account for the observed reduction in milk fat (Peterson et al., 2003); results indicated that a previously unidentified GLC peak that increased during MFD was trans-9, cis-11 CLA. We followed this with a study to examine the effects of trans-9, cis-11 CLA on milk fat production in lactating dairy cows using a mixture of CLA isomers in combination with appropriate controls.

\section{MATERIALS AND METHODS}

\section{Preliminary Data}

Milk fat samples from a previously published study involving diet-induced MFD (Peterson et al., 2003) were used to identify CLA isomers that were associated with changes in milk fat yield. Briefly, 3 midlactation Holstein cows were used in a single reversal design involving a control diet (3.46\% milk fat test) and a highconcentrate, low-forage diet (2.59\% milk fat test). Fatty acid profiles were initially analyzed by GLC procedures and compared for the 2 periods. This was followed by analysis of the CLA isomers using HPLC methods.

\section{Animals and Experimental Design}

The experiment and animal-related procedures were approved by the Cornell University Institutional Animal Care and Use Committee. Four rumen-fistulated Holstein cows (149 \pm 18 DIM; mean $\pm \mathrm{SE})$ were ran-
Table 1. Ingredient and chemical composition of the diet

\begin{tabular}{lc}
\hline Composition $^{1}$ & Concentration \\
\hline Ingredient, \% of DM & \\
Alfalfa hay & 45.0 \\
Cornmeal, coarse & 22.8 \\
Cornmeal, fine & 8.0 \\
Soybean meal (48\% CP) & 7.9 \\
Cottonseed, whole & 7.2 \\
Amino Plus & 3.2 \\
Wheat middlings & 2.7 \\
Limestone & 1.1 \\
Sodium sesquicarbonate & 0.80 \\
Molasses & 0.40 \\
Salt & 0.31 \\
Urea & 0.24 \\
Magnesium oxide & 0.11 \\
Calcium sulfate & 0.08 \\
Dairy trace mineral mix ${ }^{3}$ & 0.04 \\
Selenium & 4 \\
Vitamin mix & 5.02 \\
Chemical analysis, \% of DM & 0.02 \\
CP & \\
Crude fat & 16.0 \\
NDF & 3.2 \\
ADF & 46.1 \\
NE & Mcal/kg of DM \\
\hline
\end{tabular}

${ }^{1}$ Ingredient and chemical composition values do not include the infused conjugated linoleic acid supplements.

${ }^{2} \mathrm{Ag}$ Processing Inc. (Omaha, NE).

${ }^{3}$ Contained (g/100 g): 0.57 calcium, 15.8 sulfur, 0.41 copper, 1.22 manganese, 0.014 cobalt, 0.027 iodine, 0.10 iron, and 1.22 zinc.

${ }^{4}$ Contained $0.06 \%$ sodium selenite.

${ }^{5}$ Contained $79 \mathrm{kIU} / \mathrm{g}$ of vitamin A, $15 \mathrm{kIU} / \mathrm{g}$ of vitamin D, and 15 IU/g of vitamin E.

domly assigned in a $4 \times 4$ Latin square experiment and housed in tie stalls at the Cornell University Large Animal Teaching and Research Unit. Cows were fed a TMR formulated using the Cornell Net Carbohydrate and Protein System (Fox et al., 2004). Chopped alfalfa was the major forage component, with corn meal as the major concentrate (Table 1). Cows were fed ad libitum with equal portions of fresh feed offered at 0700 and $1900 \mathrm{~h}$ daily, and water was available at all times.

Cows were milked at 0700 and $1900 \mathrm{~h}$ daily. Yield was determined and samples were taken from each milking. One aliquot was stored with preservative (bronopol tablet; D\&F Control Systems, San Ramon, CA) at $4^{\circ} \mathrm{C}$ until analyzed for fat and protein using infrared analysis (AOAC, 2000, method 972.160; Dairy One Cooperative Inc., Ithaca, NY). The calibration reference methods for the infrared milk analysis were as described previously (Bernal-Santos et al., 2003). A second aliquot was stored without preservative at $-20^{\circ} \mathrm{C}$ until analysis of fatty acid composition.

Supplements in the form of FFA were provided by Natural ASA (Hovdebygda, Norway). Treatments were abomasal infusion of 1) ethanol (control), 2) a 9, 11 CLA mixture 3) a trans-9, trans-11 CLA supplement, and 4) 
Table 2. Fatty acids supplied by abomasal infusion of the conjugated linoleic acid (CLA) supplements

\begin{tabular}{lccc}
\hline & \multicolumn{3}{c}{ Treatment } \\
\cline { 2 - 4 } Fatty acid, g/d & $\begin{array}{c}9,11 \\
\text { CLA mix }\end{array}$ & $\begin{array}{c}t 9, t 11 \\
\text { CLA }\end{array}$ & $\begin{array}{c}t 10, c 12 \\
\text { CLA }\end{array}$ \\
\hline Cis-9, trans-11 CLA & 4.5 & $<0.1$ & 0.2 \\
Trans-9, cis-11 CLA & 5.0 & $<0.1$ & - \\
Cis-9, cis-11 CLA & 1.3 & $<0.1$ & - \\
Trans-9, trans-11 CLA & 2.6 & 5.0 & - \\
Trans-10, cis-12 CLA & 0.8 & $<0.1$ & 5.0 \\
\hline
\end{tabular}

a trans-10, cis-12 CLA supplement. Treatment periods were $5 \mathrm{~d}$ in duration, and supplements were infused 4 times daily to provide $5.0 \mathrm{~g} / \mathrm{d}$ of the isomer of interest. Daily quantities of CLA isomers provided by each supplement are presented in Table 2. The 9, 11 CLA mixture and trans-10, cis-12 CLA supplement were solubilized in 95\% ethanol at a ratio of 5:1 (ethanol:CLA) and flushed with $\mathrm{O}_{2}$-free $\mathrm{N}_{2}$ before being stored at $4^{\circ} \mathrm{C}$ until used (maximum of $5 \mathrm{~d}$ ). At each time point, equal volumes of supplement were infused through the rumen fistula into the abomasum via a 0.5 -cm (i.d.) polyvinyl chloride tubing (Spires et al., 1975). The trans-9, trans11 CLA supplement was not soluble in ethanol and was therefore weighed into gel capsules (Torpac Inc., Fairfield, NJ) and placed in the abomasum at each time point. Each treatment period was followed by a 7-d washout to minimize carryover effects in the next treatment period.

\section{Fatty Acid Analysis}

Milk fat was extracted using the method of Hara and Radin (1978) and fatty acid methyl esters were prepared by base-catalyzed transmethylation according to Christie (1982), with modifications by Chouinard et al. (1999). Fatty acid methyl esters were quantified using a gas chromatograph (GCD system HP 6890+; Hewlett-Packard, Avondale, PA) equipped with a CP-SIL 88 fused-silica capillary column [100 $\mathrm{m} \times 0.25 \mathrm{~mm}$ (i.d.) with $0.2-\mu \mathrm{m}$ film thickness; Varian, Inc., Walnut Creek, CA]. Gas-liquid chromatography conditions for milk fatty acid analysis were as described by Perfield et al. (2002).

High-performance liquid chromatographic fractionation and analysis of CLA isomers were carried out by a novel method involving a series of columns maintained at $-15^{\circ} \mathrm{C}$ (Delmonte et al., 2006). Briefly, our application used an Agilent 1100 Series chromatographic system equipped with a diode array detector (acquiring 200 to $300 \mathrm{~nm}$; Agilent Technologies, Wilmington, DE), and 3 ChromSpher 5 lipid columns (each $4.6 \mathrm{~mm}$ i.d., $250-\mathrm{mm}$ stainless steel; 5 - $\mu \mathrm{m}$ particle size;
Varian Inc.) in series maintained at $-15^{\circ} \mathrm{C}$. Conjugated linoleic acid isomers were eluted with a $2 \%$ acetic acid in hexane mobile phase at $1.0 \mathrm{~mL} / \mathrm{min}$. Single chromatograms were extracted at $233 \mathrm{~nm}$, and CLA isomers were identified using the relative retention order as described by Delmonte et al. (2005).

Fatty acid peaks were identified using pure methyl ester standards (Nu-Chek Prep, Elysian, MN). Additional standards for CLA isomers were obtained from Natural ASA or synthesized as previously reported (Delmonte et al., 2004). A butter oil reference standard (CRM 164; Commission of the European Community Bureau of References, Brussels, Belgium) was also analyzed periodically to control for column performance and calculation of correction factors for individual fatty acids.

\section{Statistical Analysis}

Data were statistically analyzed as a $4 \times 4$ Latin square design using the PROC MIXED procedure of SAS (SAS Institute, Inc., Cary, NC), in which the model was

$$
\mathrm{Y}_{\mathrm{ijk}}=\mu+\mathrm{T}_{\mathrm{i}}+\mathrm{P}_{\mathrm{j}}+\mathrm{C}_{\mathrm{k}}+\mathrm{E}_{\mathrm{ijk}},
$$

where $Y_{i j k}$ is the observation, $\mu$ is the overall mean, $T_{i}$ is treatment ( $\mathrm{i}=1,2,3$, and 4$), \mathrm{P}_{\mathrm{j}}$ is period $(\mathrm{j}=1,2,3$, and 4$), \mathrm{C}_{\mathrm{k}}$ is cow $(\mathrm{k}=1,2,3$, and 4$)$, and $\mathrm{E}_{\mathrm{ijk}}$ is residual error. Means were separated using a least significant difference test and significance was set at $P<0.05$.

\section{RESULTS AND DISCUSSION}

Previously, Peterson et al. (2003) reported that the observed reduction in milk fat yield induced by dietary changes could not be fully explained by changes in the milk fat content of trans-10, cis-12 CLA based on comparisons with dose-response studies using abomasal infusions of trans-10, cis-12 CLA. We conducted a more extensive analysis of representative milk fat samples from the investigation by Peterson et al. (2003) in an effort to identify additional fatty acids that could potentially be involved in the regulation of milk fat. In addition to an increase in the trans-10, cis-12 CLA isomer, GLC analysis of milk fat samples from cows having MFD revealed the presence of an unidentified fatty acid peak in the CLA region (Figure 1). Under the GLC conditions used, this peak could represent one of a number of CLA isomers. Therefore, to resolve the identity of this peak, HPLC analysis was performed for CLA isomers present in these milk fat samples. This subsequent analysis determined that the unknown peak found in cows having MFD was trans-9, cis-11 CLA 


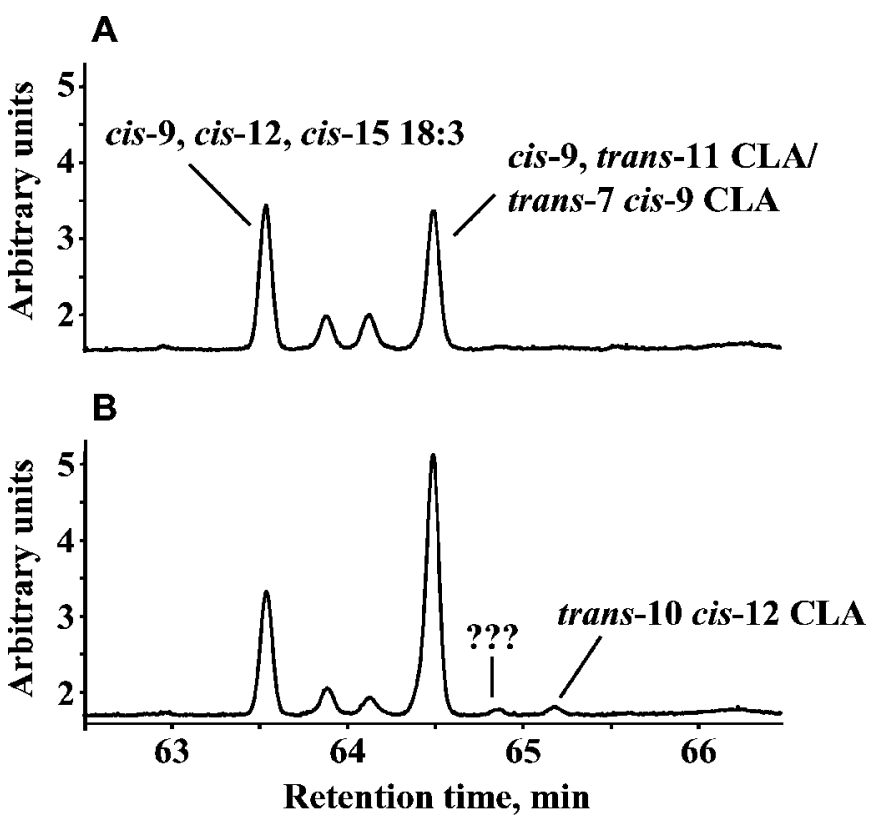

Figure 1. Partial chromatogram from gas-liquid chromatographic separation of milk fat from dairy cows fed a control (A) or milk fatdepressing ration $(\mathrm{B}) . \mathrm{CLA}=$ conjugated linoleic acid.

(Figure 2). In recent work, the trans-9, cis-11 CLA isomer has also been identified and a strong correlation found between the concentration of this fatty acid in milk fat and the milk fat content (Shingfield et al., 2005, 2006; Roy et al., 2006).

Pure trans-9, cis-11 CLA is not available, so we examined its biological effects using an enrichment $(9,11$ CLA mix) that contained this fatty acid as well as various concentrations of the other 3 geometric isomers of 9, 11 CLA (Table 2). Other major fatty acids present in the 9, 11 CLA mix were trans-9, trans-11 CLA and cis9, trans-11 CLA. The cis-9, trans-11 CLA isomer has no effect on rates of milk fat synthesis (Baumgard et al., 2000, 2002; Loor and Herbein, 2003). In contrast, the biological action of trans-9, trans-11 CLA had not been previously investigated, so a treatment providing a relatively pure form of this fatty acid $(>98 \%)$ was included for comparison. Treatments also included a positive control that received trans-10, cis-12 CLA based on its well-established ability to inhibit milk fat synthesis. Fatty acid supplements were supplied in quantities so that each provided $5 \mathrm{~g} / \mathrm{d}$ of the CLA isomer of interest (Table 2). This dose was chosen because infusion of $5 \mathrm{~g} / \mathrm{d}$ of trans-10, cis-12 CLA will cause a reduction in milk fat yield, which is less than the maximum reduction that can be achieved (de Veth et al., 2004), thereby allowing a sound comparison of the fatty acids of interest.
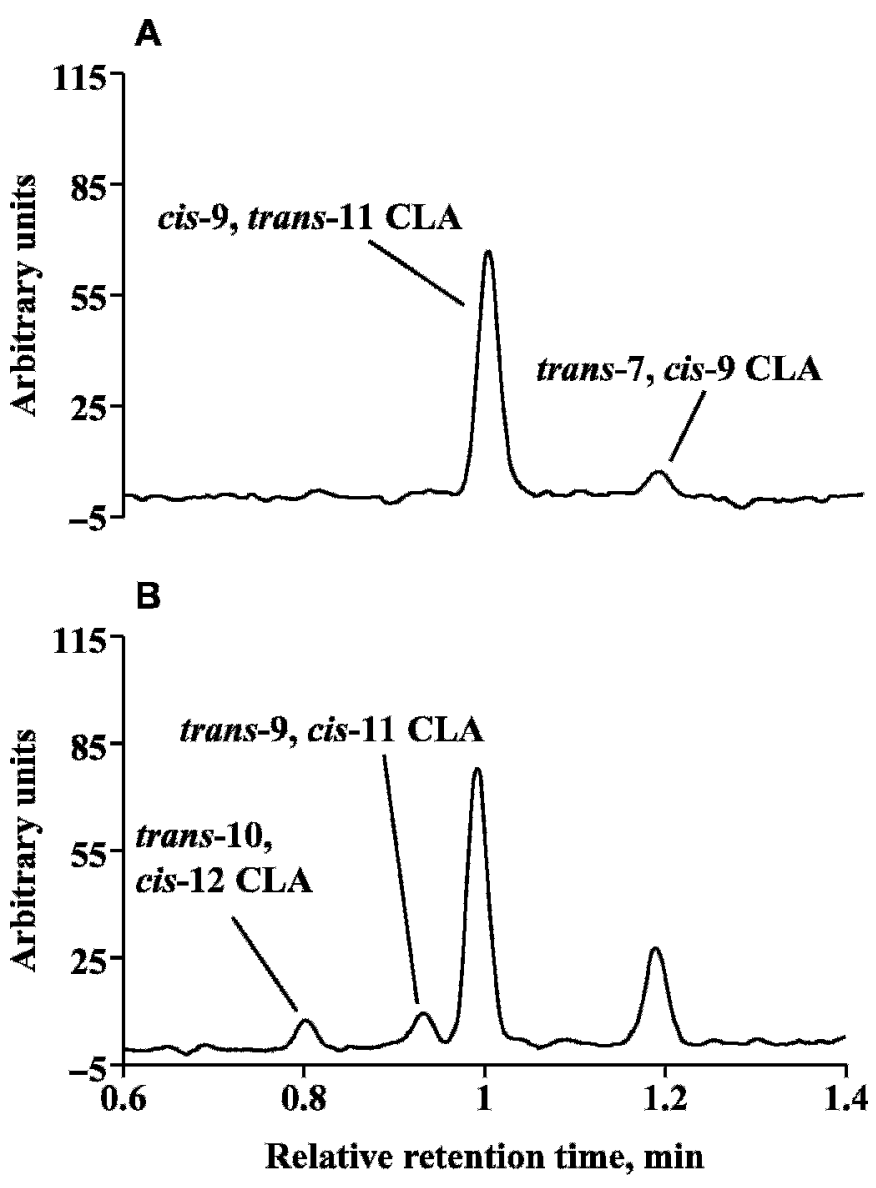

Figure 2. Partial chromatograms from silver ion high-performance liquid chromatographic separation of milk fat from dairy cows fed a control (A) or milk fat-depressing ration (B). CLA = conjugated linoleic acid.

The temporal pattern for milk fat yield demonstrated a progressive reduction for cows receiving the 9, 11 CLA mix and trans-10, cis-12 CLA supplements over the 5d infusion period, whereas no change in milk fat yield was observed for the control or trans-9, trans-11 CLA treatment groups (Figure 3). When supplements were terminated, a return to the previous milk fat yield was observed for the 9, 11 CLA mix and trans-10, cis-12 CLA treatment groups. In numerous studies investigating the effects of CLA isomers on milk fat synthesis, a similar trend has been observed for reduction in milk fat, followed by a return to previous levels after cessation of supplementation (e.g., Baumgard et al., 2000; Perfield et al., 2004).

Overall, the reduction in milk fat yield caused by the 9, 11 CLA mix was not as large as that observed for the trans-10, cis-12 CLA-supplemented animals (Table 3). Supplementation of trans-10, cis-12 CLA resulted in a $27 \%$ reduction in milk fat yield, which is comparable to the reduction observed in the dose-response summary 


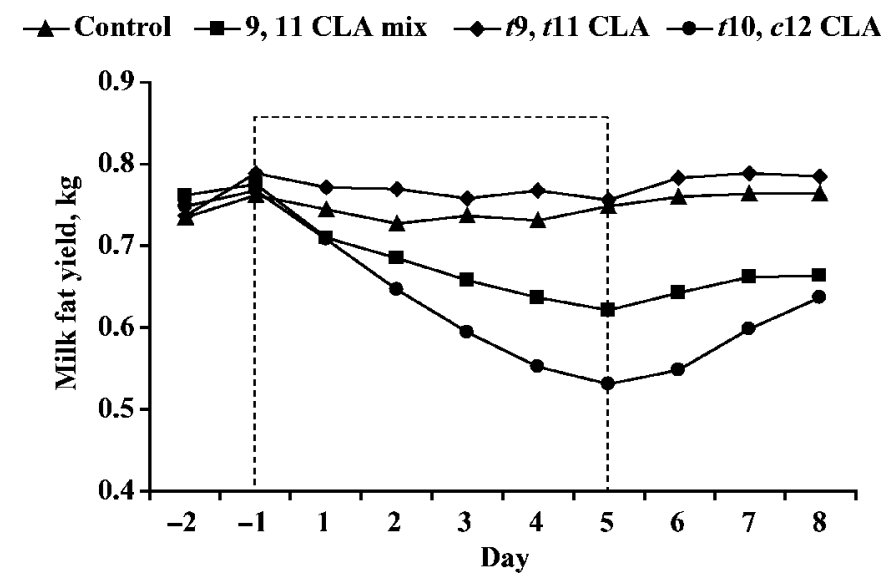

Figure 3. Temporal pattern of milk fat yield in cows during abomasal infusions of conjugated linoleic acid (CLA) supplements. Infusion period $(5 \mathrm{~d})$ indicated by the dotted line. Values represent means from 4 cows; $\mathrm{SEM}=0.03 \mathrm{~kg} / \mathrm{d}$.

of published studies (de Veth et al., 2004). In addition to trans-9, cis-11 CLA, the 9, 11 CLA mix also contained the remaining 3 geometric isomers of 9, 11 CLA. Cis9, trans-11 CLA was the second most predominant CLA isomer present in the mixture, and this CLA isomer has previously been shown not to affect milk fat synthesis (Baumgard et al., 2000, 2002; Loor and Herbein, 2003). The mixture also provided $2.6 \mathrm{~g} / \mathrm{d}$ of trans-9, trans -11 CLA (Table 2); however, the treatment providing $5 \mathrm{~g} /$ $\mathrm{d}$ of this isomer had no effect on milk fat yield (Table 3 ). Although a minor quantity of trans-10, cis-12 CLA was provided by the 9,11 CLA mix, this fatty acid was not detected in the milk fat of animals receiving this supplement (Table 4). Therefore, the biologically active isomer in the 9, 11 CLA mix that reduced milk fat synthesis was probably trans-9, cis-11 CLA, although an effect of the small amount of cis-9, cis-11 CLA (1.3 g/d) present in the mix cannot be excluded. In contrast to the effect on milk fat, CLA supplements had no effect on DMI or milk yield, but a small decrease in protein content and yield was observed when cows received the trans-9, trans-11 CLA supplement (Table 3). In general, infusions of CLA isomers do not cause changes in protein yield (Perfield et al., 2004, 2006; Sæbø et al., 2005). An explanation for this reduction in milk protein is not apparent and would require further investigation to determine whether the effect on protein is reproducible and to identify the potential mechanisms that may be involved. The lack of an effect on DMI, milk yield, and milk protein yield when a reduction in milk fat yield occurred is in agreement with other studies that have observed MFD in response to abomasally infused CLA isomers (Baumgard et al., 2001; Perfield et al., 2004; Sæbø et al., 2005).

The fatty acid composition of milk fat from the 4 experimental groups is presented in Table 4. As expected, there was a significant increase in the milk fat concentration of specific CLA isomers corresponding to those provided by the respective treatments. Therefore, all the CLA isomers were taken up by the mammary gland and incorporated into milk fat. The trans-9, trans11 CLA isomer was incorporated into milk fat less efficiently in its pure form than when provided by the 9 , 11 CLA mix. This could be due to differences in digestibility because the pure trans-9, trans-11 CLA was solid at room temperature and potentially less digestible. Fortuitously, cows receiving the 9, 11 CLA mix and the trans-9, trans-11 CLA treatment secreted a similar amount of trans-9, trans-11 CLA in the milk fat (1.4 vs. $1.1 \mathrm{~g} / \mathrm{d}$, respectively), thereby allowing for an accurate interpretation of the lack of an effect on milk fat synthesis. In addition, $9 \mathrm{~g} / \mathrm{d}$ of trans-9, trans-11 CLA abomasally infused over a 4-d period had no effect on milk fat synthesis (data not shown). Consistent with other

Table 3. Performance of lactating dairy cows during abomasal infusions ${ }^{1}$

\begin{tabular}{llccccc}
\hline & \multicolumn{7}{c}{ Treatment } \\
\cline { 2 - 6 } Variable & Control & $\begin{array}{c}9,11 \mathrm{CLA} \\
\text { mix }\end{array}$ & $\begin{array}{c}t 9, t 11 \\
\text { CLA }\end{array}$ & $\begin{array}{c}t 10, c 12 \\
\text { CLA }\end{array}$ & SEM & $P$ \\
\hline DMI, kg/d & 19.1 & 19.6 & 18.2 & 18.3 & 0.6 & 0.06 \\
Milk, kg/d & 20.6 & 20.4 & 19.1 & 21.4 & 0.8 & 0.08 \\
Milk fat & & & & & & \\
\% & $3.60^{\mathrm{b}}$ & $3.07^{\mathrm{c}}$ & $4.03^{\mathrm{a}}$ & $2.54^{\mathrm{d}}$ & 0.15 & $<0.001$ \\
kg/d & $0.740^{\mathrm{a}}$ & $0.628^{\mathrm{b}}$ & $0.770^{\mathrm{a}}$ & $0.541^{\mathrm{c}}$ & 0.028 & $<0.001$ \\
Milk protein & & & & & & \\
$\quad \%$ & $3.01^{\mathrm{a}}$ & $3.01^{\mathrm{a}}$ & $2.87^{\mathrm{b}}$ & $3.02^{\mathrm{a}}$ & 0.13 & $<0.001$ \\
kg/d & $0.617^{\mathrm{a}}$ & $0.615^{\mathrm{a}}$ & $0.547^{\mathrm{b}}$ & $0.648^{\mathrm{a}}$ & 0.043 & $<0.01$ \\
Milk lactose & & & & & & \\
$\quad \%$ & $4.76^{\mathrm{a}}$ & $4.64^{\mathrm{b}}$ & $4.78^{\mathrm{a}}$ & $4.68^{\mathrm{b}}$ & 0.06 & $<0.01$ \\
kg/d & 0.97 & 0.94 & 0.92 & 1.00 & 0.04 & 0.37 \\
\hline
\end{tabular}

${ }^{\mathrm{a}-\mathrm{d}}$ Means within a row with different superscripts differ $(P<0.05)$.

${ }^{1}$ Values represent an average of $d 4$ and 5 of conjugated linoleic acid (CLA) supplementation. 
Table 4. Composition of milk fat during abomasal infusions ${ }^{1}$

\begin{tabular}{|c|c|c|c|c|c|c|}
\hline \multirow[b]{2}{*}{ Fatty acid, \% } & \multicolumn{4}{|c|}{ Treatment } & \multirow[b]{2}{*}{ SEM } & \multirow[b]{2}{*}{$P$} \\
\hline & Control & $\begin{array}{c}9,11 \\
\text { CLA mix }\end{array}$ & $\begin{array}{c}t 9, t 11 \\
\text { CLA }\end{array}$ & $\begin{array}{c}t 10, c 12 \\
\text { CLA }\end{array}$ & & \\
\hline $4: 0$ & $3.43^{\mathrm{c}}$ & $3.85^{\mathrm{a}}$ & $3.53^{\mathrm{bc}}$ & $3.69^{\mathrm{ab}}$ & 0.13 & $<0.001$ \\
\hline $6: 0$ & $1.85^{\mathrm{a}}$ & $1.86^{\mathrm{a}}$ & $1.85^{\mathrm{a}}$ & $1.49^{\mathrm{b}}$ & 0.12 & $<0.001$ \\
\hline 8:0 & $0.99^{\mathrm{a}}$ & $0.97^{\mathrm{a}}$ & $0.98^{\mathrm{a}}$ & $0.72^{\mathrm{b}}$ & 0.09 & $<0.001$ \\
\hline 10:0 & $2.02^{\mathrm{a}}$ & $1.98^{\mathrm{a}}$ & $2.01^{\mathrm{a}}$ & $1.47^{\mathrm{b}}$ & 0.21 & $<0.001$ \\
\hline 12:0 & $2.25^{\mathrm{ab}}$ & $2.31^{\mathrm{a}}$ & $2.14^{\mathrm{b}}$ & $1.90^{\mathrm{c}}$ & 0.24 & $<0.001$ \\
\hline 14:0 & $8.63^{\mathrm{b}}$ & $9.32^{\mathrm{a}}$ & $8.19^{b}$ & $8.22^{\mathrm{b}}$ & 0.66 & $<0.001$ \\
\hline $14: 1$ & $0.79^{\mathrm{a}}$ & $0.75^{\mathrm{ab}}$ & $0.51^{\mathrm{c}}$ & $0.68^{\mathrm{b}}$ & 0.10 & $<0.001$ \\
\hline $15: 0$ & $0.84^{\mathrm{b}}$ & $0.90^{\mathrm{a}}$ & $0.76^{\mathrm{c}}$ & $0.87^{\mathrm{ab}}$ & 0.04 & $<0.001$ \\
\hline $16: 0$ & $26.77^{\mathrm{a}}$ & $25.45^{\mathrm{b}}$ & $25.79^{b}$ & $23.73^{\mathrm{c}}$ & 0.67 & $<0.001$ \\
\hline $16: 1$ & $1.52^{\mathrm{a}}$ & $1.15^{\mathrm{c}}$ & $1.28^{\mathrm{bc}}$ & $1.32^{\mathrm{b}}$ & 0.10 & $<0.001$ \\
\hline $17: 0$ & $0.57^{\mathrm{b}}$ & $0.54^{\mathrm{b}}$ & $0.60^{\mathrm{ab}}$ & $0.65^{\mathrm{a}}$ & 0.05 & $<0.01$ \\
\hline 18:0 & $12.78^{\mathrm{c}}$ & $13.98^{\mathrm{bc}}$ & $15.64^{\mathrm{a}}$ & $15.18^{\mathrm{ab}}$ & 0.79 & $<0.001$ \\
\hline $18: 1$ trans -6 to 8 & 0.37 & 0.38 & 0.33 & 0.43 & 0.03 & 0.09 \\
\hline 18:1 trans -9 & 0.27 & 0.29 & 0.25 & 0.27 & 0.01 & 0.10 \\
\hline $18: 1$ trans -10 & 0.39 & 0.42 & 0.40 & 0.44 & 0.03 & 0.21 \\
\hline $18: 1$ trans -11 & $1.28^{\mathrm{b}}$ & $1.37^{\mathrm{a}}$ & $1.39^{\mathrm{a}}$ & $1.41^{\mathrm{a}}$ & 0.04 & $<0.05$ \\
\hline 18:1 trans -12 & 0.41 & 0.43 & 0.40 & 0.43 & 0.02 & 0.43 \\
\hline $18: 1$ cis -9 & $27.50^{\mathrm{b}}$ & $25.81^{\mathrm{c}}$ & $26.35^{\mathrm{bc}}$ & $28.92^{\mathrm{a}}$ & 1.61 & $<0.001$ \\
\hline $18: 2$ cis -9, cis -12 & $3.28^{\mathrm{bc}}$ & $3.16^{\mathrm{c}}$ & $3.43^{\mathrm{b}}$ & $3.68^{\mathrm{a}}$ & 0.19 & $<0.001$ \\
\hline $18: 2$ cis -9, trans $-11^{2}$ & $0.51^{\mathrm{b}}$ & $0.91^{\mathrm{a}}$ & $0.45^{\mathrm{b}}$ & $0.50^{\mathrm{b}}$ & 0.04 & $<0.001$ \\
\hline $18: 2$ trans -9, cis- 11 & $<0.01^{\mathrm{b}}$ & $0.38^{\mathrm{a}}$ & $<0.01^{\mathrm{b}}$ & $<0.01^{\mathrm{b}}$ & 0.02 & $<0.001$ \\
\hline $18: 2$ trans -10, cis- 12 & $<0.01^{\mathrm{b}}$ & $<0.01^{\mathrm{b}}$ & $<0.01^{b}$ & $0.21^{\mathrm{a}}$ & 0.02 & $<0.001$ \\
\hline $18: 2$ cis -9, cis- 11 & $<0.01^{\mathrm{b}}$ & $0.09^{\mathrm{a}}$ & $<0.01^{\mathrm{b}}$ & $<0.01^{\mathrm{b}}$ & $<0.01$ & $<0.001$ \\
\hline $18: 2$ trans -9, trans -11 & $<0.01^{\mathrm{c}}$ & $0.23^{\mathrm{a}}$ & $0.14^{\mathrm{b}}$ & $0.01^{\mathrm{c}}$ & 0.01 & $<0.001$ \\
\hline $18: 3$ & $0.46^{\mathrm{c}}$ & $0.48^{\mathrm{bc}}$ & $0.52^{\mathrm{a}}$ & $0.50^{\mathrm{ab}}$ & 0.03 & $<0.001$ \\
\hline $20: 0$ & $0.11^{\mathrm{c}}$ & $0.12^{\mathrm{b}}$ & $0.13^{\mathrm{a}}$ & $0.12^{\mathrm{ab}}$ & 0.01 & $<0.001$ \\
\hline Other & $2.99^{b}$ & $3.10^{\mathrm{ab}}$ & $2.97^{\mathrm{b}}$ & $3.17^{\mathrm{a}}$ & 0.06 & $<0.05$ \\
\hline \multicolumn{7}{|l|}{ Summation $^{3}$} \\
\hline$<\mathrm{C}_{16}$ & $19.97^{\mathrm{b}}$ & $21.03^{\mathrm{a}}$ & $19.22^{\mathrm{b}}$ & $18.18^{\mathrm{c}}$ & 1.42 & $<0.001$ \\
\hline $\mathrm{C}_{16}+16: 1$ & $28.29^{\mathrm{a}}$ & $26.60^{\mathrm{b}}$ & $27.08^{\mathrm{b}}$ & $25.05^{\mathrm{c}}$ & 0.62 & $<0.001$ \\
\hline$>\mathrm{C}_{16}$ & $51.18^{\mathrm{c}}$ & $52.06^{\mathrm{bc}}$ & $53.10^{\mathrm{b}}$ & $56.12^{\mathrm{a}}$ & 1.73 & $<0.001$ \\
\hline \multicolumn{7}{|l|}{ Desaturase index ${ }^{4}$} \\
\hline $14: 1 /(14: 0+14: 1)$ & $0.082^{\mathrm{a}}$ & $0.074^{\mathrm{b}}$ & $0.058^{\mathrm{c}}$ & $0.077^{\mathrm{ab}}$ & 0.008 & $<0.001$ \\
\hline $16: 1 /(16: 0+16: 1)$ & $0.054^{\mathrm{a}}$ & $0.044^{\mathrm{b}}$ & $0.048^{\mathrm{b}}$ & $0.052^{\mathrm{a}}$ & 0.004 & $<0.001$ \\
\hline $18: 1 /(18: 0+18: 1)$ & $0.684^{\mathrm{a}}$ & $0.649^{\mathrm{bc}}$ & $0.626^{\mathrm{c}}$ & $0.655^{\mathrm{b}}$ & 0.017 & $<0.001$ \\
\hline$c 9, t 11$ CLA $/(18: 1 t 11+c 9, t 11$ CLA $)$ & $0.284^{\mathrm{b}}$ & $0.397^{\mathrm{a}}$ & $0.246^{\mathrm{c}}$ & $0.261^{\mathrm{bc}}$ & 0.018 & $<0.001$ \\
\hline
\end{tabular}

${ }^{\mathrm{a}-\mathrm{c}}$ Means within a row with different superscripts differ $(P<0.05)$.

${ }^{1}$ Values represent an average of $\mathrm{d} 4$ and 5 of conjugated linoleic acid (CLA) supplementation.

${ }^{2}$ Includes trans-7, cis-9 CLA.

${ }^{3}$ Fatty acids are categorized according to origin: $<\mathrm{C}_{16}$ represent de novo synthesized fatty acids, $>\mathrm{C}_{16}$ represent preformed fatty acids taken up from circulation, and $\mathrm{C}_{16}$ fatty acids are derived from both sources.

${ }^{4}$ Desaturase index calculated for 4 pairs of fatty acids that represent products and substrates for $\Delta^{9}$ desaturase. Defined as [product of $\Delta^{9}$-desaturase]/[product of $\Delta^{9}$-desaturase + substrate of $\Delta^{9}$-desaturase].

studies, trans-10, cis-12 CLA supplementation resulted in a reduced milk fat content of fatty acids $\leq 16$ carbons in length and a proportional increase in fatty acids longer than 16 carbons in length (Table 4). In contrast, MFD induced by the 9, 11 CLA mixture reduced the milk fat content of only 16 -carbon fatty acids. This subtle difference in compositional changes may be related to the magnitude of reduction in milk fat caused by the 2 treatments (Baumgard et al., 2001; Peterson et al., 2002).

Fluidity of fat is an important consideration in the mammary gland's ability to secrete milk fat (Timmen and Patton, 1988), and the enzyme $\Delta^{9}$-desaturase plays a key role in determining milk fat fluidity. The desatur- ase index represents a proxy for $\Delta^{9}$-desaturase in the mammary gland and is calculated from fatty acid pairs that represent the substrate-product for this enzyme (Bauman et al., 2003). The 9, 11 CLA mix caused a reduction in milk fat as well as a shift in the desaturase index. The trans-9, trans-11 CLA supplement altered milk fatty acid composition, and this resulted in marked shifts in the desaturase indices. The trans-10, cis-12 CLA isomer also caused a slight reduction in one of the desaturase indices (Table 4).

Milk fat desaturase indices are often altered during diet-induced MFD. However, in previous studies with trans-10, trans-12 CLA (Sæbø et al., 2005; Perfield et al., 2006) and sterculic oil (Griinari et al., 2000; Corl 
et al., 2001; Kay et al., 2004), reductions have been observed in the desaturase index with no change in milk fat production. A reduction in milk fat yield can also occur without any change in the desaturase index, and this is typically observed at low doses of trans-10, cis-12 CLA when the reduction in milk fat is less than 20 to 25\% (Baumgard et al., 2001; Peterson et al., 2002). Overall, these results illustrate the considerable latitude that the mammary gland must have in maintaining an appropriate milk fat fluidity. Perfield et al. (2006) previously recognized that an alteration in the desaturase index ( $\Delta^{9}$-desaturase) is neither a prerequisite for, nor a major component in, the development of MFD. Data from the present study with the trans-9, trans-11 CLA treatment further demonstrate the disconnect that can exist between changes in $\Delta^{9}$-desaturase and milk fat yield.

The current study indicates an involvement of trans9, cis-11 CLA in certain situations of diet-induced MFD. This represents only the third biohydrogenation intermediate identified as having an inhibitory effect on milk fat synthesis, the others being the well-established ability of trans-10, cis-12 CLA (see review by Bauman and Griinari, 2003) and the recent identification of cis-10, trans-12 CLA (Sæbø et al., 2005). A number of additional CLA isomers have been investigated, including trans-8, cis-10 CLA, cis-9, trans-11 CLA, trans-9, trans11 CLA, trans-10, trans-12 CLA, and cis-11, trans-13 CLA (Baumgard et al., 2000; Perfield et al., 2004, 2006; Sæbø et al., 2005; present study). Although all these CLA isomers were incorporated into milk fat, none had any effect on the yield of milk fat. Likewise, several trans-18:1 biohydrogenation intermediates have been investigated, including trans-9 18:1, trans-11 18:1, and trans-12 18:1, and none had an effect on milk fat synthesis at the doses examined (Rindsig and Schultz, 1974; Griinari et al., 2000). More recently, the effects of relatively pure trans-10 18:1 were examined and it also had no effect on milk fat synthesis (Lock et al., 2007). However, it is important to note that the identification of cis-10, trans-12 CLA (Sæbø et al., 2005) and trans9, cis-11 CLA (present study) as potential inhibitors of milk fat synthesis requires additional verification. For both isomers, investigations demonstrating their inhibitory effects on milk fat synthesis used CLA enrichments at a single dose in an investigation with limited animal numbers. Thus, replicating these findings with pure CLA isomers at multiple doses will be necessary to establish their potency and clarify their potential role in the regulation of milk fat synthesis. Nevertheless, tracking the occurrence of these fatty acids under different dietary conditions and their correlation with changes in milk fat will be valuable in understanding and troubleshooting the phenomenon of diet-induced MFD.

Overall, our investigations identified an increase in trans-9, cis-11 CLA with diet-induced MFD and then tested the effects of this CLA isomer on milk fat synthesis. Our results provide evidence of a role for this isomer in MFD based on the 15\% reduction in milk fat yield that occurred with abomasal infusion of $5 \mathrm{~g} / \mathrm{d}$ of this isomer. In addition, we established that trans-9, trans11 CLA had no effect on milk fat yield, although it was incorporated into milk fat and resulted in an inhibition of $\Delta^{9}$-desaturase, as indicated by the marked alterations in the desaturase indices of milk fat.

\section{ACKNOWLEDGMENTS}

The assistance of the following students and colleagues at Cornell University in implementing the study is gratefully acknowledged and appreciated: B. English, L. Furman, E. Johnson, B. Jones, and E. Vanstrom.

\section{REFERENCES}

AOAC (Association of Official Analytical Chemists). 2000. Official Methods of Analysis. 17th ed. AOAC International, Arlington, VA.

Bauman, D. E., B. A. Corl, and D. G. Peterson. 2003. Biology of conjugated linoleic acid in ruminants. Pages 146-173 in Advances in Conjugated Linoleic Acid Research, Vol. II. J. L. Sébédio, W. W. Christie, and R. O. Adlof, ed. AOCS Press, Champaign, IL.

Bauman, D. E., and J. M. Griinari. 2001. Regulation and nutritional manipulation of milk fat: Low-fat milk syndrome. Livest. Prod. Sci. 70:15-29.

Bauman, D. E., and J. M. Griinari. 2003. Nutritional regulation of milk fat synthesis. Annu. Rev. Nutr. 23:203-227.

Baumgard, L. H., B. A. Corl, D. A. Dwyer, and D. E. Bauman. 2002. Effects of conjugated linoleic acids (CLA) on tissue response to homeostatic signals and plasma variables associated with lipid metabolism in lactating cows. J. Anim. Sci. 80:1285-1293.

Baumgard, L. H., B. A. Corl, D. A. Dwyer, A. Sæbø, and D. E. Bauman. 2000. Identification of the conjugated linoleic acid isomer that inhibits milk fat synthesis. Am. J. Physiol. Regul. Integr. Comp. Physiol. 278:R179-R184.

Baumgard, L. H., J. K. Sangster, and D. E. Bauman. 2001. Milk fat synthesis in dairy cows is progressively reduced by increasing supplemental amounts of trans-10, cis-12 conjugated linoleic acid (CLA). J. Nutr. 131:1764-1769.

Bernal-Santos, G., J. W. Perfield, D. M. Barbano, D. E. Bauman, and T. R. Overton. 2003. Production responses of dairy cows to dietary supplementation with conjugated linoleic acid (CLA) during the transition period and early lactation. J. Dairy Sci. 86:3218-3228.

Chouinard, P. Y., L. Corneau, D. M. Barbano, L. E. Metzger, and D. E. Bauman. 1999. Conjugated linoleic acids alter milk fatty acid composition and inhibit milk fat secretion in dairy cows. J. Nutr. 129:1579-1584.

Christie, W. W. 1982. A simple procedure for rapid transmethylation of glycerolipids and cholesteryl esters. J. Lipid Res. 23:1072-1075.

Corl, B. A., L. H. Baumgard, D. A. Dwyer, J. M. Griinari, B. S. Phillips, and D. E. Bauman. 2001. The role of delta(9)-desaturase in the production of cis-9, trans-11 CLA. J. Nutr. Biochem. 12:622-630.

Delmonte, P., A. Kataoka, B. A. Corl, D. E. Bauman, and M. P. Yurawecz. 2005. Relative retention order of all isomers of cis/ trans conjugated linoleic acid FAME from the 6,8 to 13,15 positions using silver ion HPLC with 2 different elution systems. Lipids 40:509-514. 
Delmonte, P., J. K. G. Kramer, S. Banni, and M. P. Yurawecz. 2006. New developments in silver ion and reverse phase HPLC of conjugated linoleic acid. Pages 95-118 in Advances in Conjugated Linoleic Acid Research, Vol. III. M. P. Yurawecz, J. K. G. Kramer, O. Gudmundsen, M. W. Pariza, and S. Banni, ed. AOCS Press, Champaign, IL.

Delmonte, P., J. A. Roach, M. M. Mossoba, G. Losi, and M. P. Yurawecz. 2004. Synthesis, isolation, and GC analysis of all the 6,8to 13,15-cis/trans conjugated linoleic acid isomers. Lipids 39:185-191.

de Veth, M. J., J. M. Griinari, A. M. Pfeiffer, and D. E. Bauman. 2004. Effect of CLA on milk fat synthesis in dairy cows: Comparison of inhibition by methyl esters and free fatty acids, and relationships among studies. Lipids 39:365-372.

Fox, D. G., L. O. Tedeschi, T. P. Tylutki, J. B. Russell, M. E. Van Amburgh, L. E. Chase, A. N. Pell, and T. R. Overton. 2004. The Cornell Net Carbohydrate and Protein System model for evaluating herd nutrition and nutrient excretion. Anim. Feed Sci. Technol. 112:29-78.

Griinari, J. M., B. A. Corl, S. H. Lacy, P. Y. Chouinard, K. V. Nurmela, and D. E. Bauman. 2000. Conjugated linoleic acid is synthesized endogenously in lactating dairy cows by $\Delta^{9}$-desaturase. J. Nutr. 130:2285-2291.

Hara, A., and N. S. Radin. 1978. Lipid extraction of tissues with a low-toxicity solvent. Anal. Biochem. 90:420-426.

Kay, J. K., T. R. Mackle, M. J. Auldist, N. A. Thomson, and D. E. Bauman. 2004. Endogenous synthesis of cis-9, trans-11 conjugated linoleic acid in dairy cows fed fresh pasture. J. Dairy Sci. 87:369-378.

Lock, A. L., C. Tyburczy, D. A. Dwyer, K. J. Havatine, F. Destaillats, Z. Mouloungui, L. Candy, and D. E. Bauman. 2007. Trans-10 octadecenoic acid does not reduce milk fat synthesis in dairy cows. J. Nutr. 137:71-76.

Loor, J. J., A. Ferlay, A. Ollier, M. Doreau, and Y. Chilliard. 2005. Relationship among trans and conjugated fatty acids and bovine milk fat yield due to dietary concentrate and linseed oil. J. Dairy Sci. 88:726-740.

Loor, J. J., and J. H. Herbein. 2003. Reduced fatty acid synthesis and desaturation due to exogenous trans10, cis12-CLA in cows fed oleic or linoleic oil. J. Dairy Sci. 86:1354-1369.

Perfield, J. W., II, G. Bernal-Santos, T. R. Overton, and D. E. Bauman. 2002. Effects of dietary supplementation of rumen-protected conjugated linoleic acid in dairy cows during established lactation. J. Dairy Sci. 85:2609-2617.
Perfield, J. W., II, P. Delmonte, A. L. Lock, M. P. Yurawecz, and D. E. Bauman. 2006. Trans-10, trans-12 conjugated linoleic acid does not affect milk fat yield but reduces $\Delta^{9}$-desaturase index in dairy cows. J. Dairy Sci. 89:2559-2566.

Perfield, J. W., II, A. Sæbø, and D. E. Bauman. 2004. Use of conjugated linoleic acid (CLA) enrichments to examine the effects of trans8, cis-10 CLA, and cis-11, trans-13 CLA on milk-fat synthesis. J. Dairy Sci. 87:1196-1202.

Peterson, D. G., L. H. Baumgard, and D. E. Bauman. 2002. Short communication: Milk fat response to low doses of trans-10, cis12 conjugated linoleic acid (CLA). J. Dairy Sci. 85:1764-1766.

Peterson, D. G., E. A. Matitashvili, and D. E. Bauman. 2003. Dietinduced milk fat depression in dairy cows results in increased trans-10, cis-12 CLA in milk fat and coordinate suppression of mRNA abundance for mammary enzymes involved in milk fat synthesis. J. Nutr. 133:3098-3102.

Rindsig, R. B., and L. H. Schultz. 1974. Effects of abomasal infusions of safflower oil or elaidic acid on blood lipids and milk fat in dairy cows. J. Dairy Sci. 57:1459-1466.

Roy, A., A. Ferlay, K. J. Shingfield, and Y. Chilliard. 2006. Examination of the persistency of milk fatty acid composition responses to plant oils in cows given different basal diets, with particular emphasis on trans- $\mathrm{C}_{18: 1}$ fatty acids and isomers of conjugated linoleic acid. Anim. Sci. 82:479-492.

Sæbø, A., P. Sæbø, J. M. Griinari, and K. J. Shingfield. 2005. Effect of abomasal infusion of geometric isomers of 10,12 conjugated linoleic acid on milk fat synthesis in dairy cows. Lipids 40:823-832.

Shingfield, K. J., C. K. Reynolds, G. Hervas, J. M. Griinari, A. S. Grandison, and D. E. Beever. 2006. Examination of the persistency of milk fatty acid composition responses to fish oil and sunflower oil in the diet of dairy cows. J. Dairy Sci. 89:714-732.

Shingfield, K. J., C. K. Reynolds, B. Lupoli, V. Toivonen, M. P. Yurawecz, P. Delmonte, J. M. Griinari, A. S. Grandison, and D. E. Beever. 2005. Effect of forage type and proportion of concentrate in the diet on milk fatty acid composition in cows given sunflower oil and fish oil. Anim. Sci. 80:225-238.

Spires, H. R., J. H. Clark, R. G. Derrig, and C. L. Davis. 1975. Milk production and nitrogen utilization in response to postruminal infusion of sodium caseinate in lactating cows. J. Nutr. 105:1111-1121.

Timmen, H., and S. Patton. 1988. Milk fat globules: Fatty acid composition, size and in vivo regulation of fat liquidity. Lipids 23:685-689. 